\title{
NILAI-NILAI KEARIFAN LOKAL DALAM PERIODE TOMANURUNG
}

\author{
Yunus \\ STMIK Eresha, Kota Tangerang Selatan, Banten, Indonesia \\ Email: nurhang542@gmail.com
}

\begin{abstract}
This study aims to describe the value of local wisdom contained in the Tomanurung period. This research uses ethno pedagogical method. The technique of collecting data through interviews, interviewed informants came from several academic circles (lecturers) as many as 6 people. Researchers also interviewed 6 community leaders. This post-chaos period is called the Tomanurung period with a character named Simpurusiang in Bugis language, "Simpurusiang" implies "a strong and unbroken binder". The condition of society is in a state of chaos and divorce. Because of this, they are looking for figures who can unite societies that have been divided and in chaos. Through a long search, they found the person they needed, namely a Tomanurung (the descendant) and they agreed to make him king through a "collective agreement" that is between Tomanurung and people's representatives. According to the perspective of the Luwn community, Tomanurung means a person who descends from heaven or heaven. Tomanurung did not know the news of his arrival beforehand, suddenly appeared and his presence was being awaited to fix the chaotic situation. Therefore, Tomanurung for the people of Luwn and Bugis-Makassar is generally considered a savior, unifier and continuation of royal life. So the value of human behavior in the past, which was the source of the lontaraq pappaseng script, such as adele' (fair), lempu' (bonest), getteng (firm), Abbulo Sibatang.
\end{abstract}

Keyword: PeriodeTomanurung; Nilai kearifan lokal

Abstrak. Penelitian ini bertujuan mengambarkan nilai kearifan lokal yang terdapat dalam periode Tomanurung. Penelitian ini menggunakan metode etnopedagogi. Teknik pengumpulan datanya melalui wawancara, informan yang diwawancarai berasal dari beberapa kalangan dari akademis (Dosen) sebanyak 6 orang. Peneliti juga, mewawancarai kalangan tokoh masyarakat sebanyak 6 orang. Periode pasca chaos ini disebut dengan periode Tomanurung dengan tokohnya bernama Simpurusiang dalam Bahasa Bugis, "Simpurusiang" mengandung makna "pengikat yang kuat dan tidak putus-putus". Karena kondisi masyarakat dalam keadaan kacau dan bercerai berai. Karena itu, mereka mencari tokoh yang dapat mempersatukan masyarakat yang telah bercerai-berai dan dalam keadaan kacau (chaos). Melalui pencarian yang panjang, maka ditemukanlah orang yang mereka perlukan yaitu seorang Tomanurung (orang turun) dan mereka sepakat menjadikannya raja melalui suatu "perjanjian bersama" yaitu antara Tomanurung dengan wakil- wakil rakyat. Menurut persfektif masyarakat Luwu, Tomanurung artinya orang yang turun dari langit atau kayangan. Tomanurung tidak diketahui berita kedatangannya terlebih dahulu, tiba-tiba muncul dan kehadirannya memang sedang ditunggu-tunggu untuk memperbaiki keadaan yang sedang kacau. Karena itu, Tomanurung bagi masyarakat Luwu dan Bugis-Makassar pada umumnya dianggap sebagai penyelamat, pemersatu dan pelanjut kehidupan kerajaan. Jadi nilai perilaku manusia pada masa lampau yang sumber naskah lontaraq pappaseng seperti adele' (adil), lempu' (jujur), getteng (teguh), Abbulo Sibatang.

Kata Kunci: Periode'Tomanurung; Nilai kearifan local 


\section{Pendahuluan}

Periode Tomanurung atau periode Lontara (periode sejarah), masyarakat Luwu mengenal zaman I Lagaligo yaitu zaman pemerintahan para dewa dari botinglangi (langit) dan dari peretiwi (dunia Bawah) karena para dewa-dewa yang memerintah di ale kawa (dunia tengah) kembali ke tempatnya masingmasing. Sehingga pada akhir periode Galigo, dikisahkan rakyat tidak mempunyai raja lagi, maka terjadilah kekacauan (chaos) yang disebut dengan masa sianrebale (bomo homoni lupus). Mereka hidup dalam kelompok-kelompok dengan kepala kelompok masing-masing yang disebut dengan anang. Antara satu kelompok dengan kelompok yang lain saling bermusuhan dan saling bunuh-membunuh. Zaman ini, oleh Pelras disebut dengan zaman anarkis atau kekacauan. Zaman tersebut berlangsung cukup lama, kurang lebih pitu pariama (mungkin yang dimaksud tujuh generasi atau tujuh puluh tujuh tahun). Selama masa sianrebale, sistem kelembagaan masyarakat Luwu yang disebut anang, macet. Terjadi kekosongan kekuasaan. Ciri masyarakat ini adalah anarkis, tanpa aspirasi, tanpa adat, tanpa hukum, dan tanpa peradilan. Antara satu kelompok dengan kelompok lainnya saling menerkam. Konflik yang berlarutlarut ini menyadarkan bahwa masyarakat Luwu makin jauhnya mereka dari tujuan kemanusiaan. Masyarakat Luwu kemudian sadar akan perlunya menciptakan perdamaian yang kekal di antara masyarakat kaum (anang).

Sejak periode I Galigo hingga Lontara, telah berperan penting dalam membangun tatanan masyarakat di beberapa wilayah. Berbagai wilayah di Sulawesi Selatan, kerap menghubungkan keturunannya atau keberadaan kerajaannya dengan kerajaan Luwu. Dengan demikian dapatlah dikatakan bahwa Luwu merupakan akar kebudayaan yang telah berintegrasi dalam wilayah kesadaran masyarakat pendukungnya.

Keagungan dan kearifan sejarah dan kebudayaan Luwu telah menjadi kekuatan tersendiri dalam menyerap dan mentransformasikan berbagai anasir kebudayaan dari luar yang kemudian berintegrasi dalam sebuah harmonisasi kebudayaan. Sejarah terlebih kebudayaan Luwu terus mengalami aliansi dari masyarakatnya sendiri. Kondisi ini semakin diperparah oleh adanya kecenderungan terjadinya proses politisasi sejarah dan kebudayaan. Hal ini tentunya juga akan menjadikan sejarah dan kebudayaan Luwu mengalami keterasingan dari pusat kesadaran masyarakat Luwu sendiri.

Nilai-nilai budaya sebagai salah satu bentuk kearifan lokal yang dimiliki oleh Kerajaan Luwu pada pelaksanaannya mengalami penurunan secara drastis akibat dilupakannya nilai-nilai yang seharusnya menjadi landasan dalam pemerintahan. Hal ini ditandai dengan lemahnya pemahaman masyarakat Luwu tentang budaya yang tentunya mengandung unsur-unsur nilai yang begitu berharga untuk kemudian diterapkan dalam kehidupan bermasyarakat utamanya di bidang pemerintahan (aparatur). Penulis mencoba mengangkat hal-hal yang terkait dengan nilai-nilai yang dahulunya menjadi panutan dalam praktek kehidupan masyarakat, khususnya pada penyelenggaraan pemerintahan pada masa Kerajaan Luwu (To Ciung Maccae ri Luwu).

Nilai budaya merupakan sesuatu yang abstrak yang dijadikan pedoman serta prinsip- prinsip umum dalam bertindak dan bertingkah laku. Keterikatan orang atau kelompok terhadap nilai budaya relatif sangat kuat dan bahkan bersifat emosional. Oleh sebab itu, nilai budaya dapat dilihat sebagai tujuan kehidupan manusia itu sendiri. Bertitik tolak dari pendapat tersebut, maka dapat dikatakan bahwa setiap individu dalam melaksanakan aktifitas sosialnya selalu berdasarkan serta berpedoman kepada nilai-nilai atau sistem nilai yang ada dan hidup dalam masyarakat itu sendiri. Nilai yang dimaksud 
adalah nilai To Ciung Maccae Ri Luwu yang ajarannya antara lain yaitu adele' (adil), lempu' (jujur) dan getting (teguh).

Salah satu falsafah "resopa temmangngingi namalomo naletei pammase dewata" falsafah ini memiliki arti orang Bugis menyakini bahwa semua keberhasilan karena adanya rahmat atau kasih sayang dan pertolongan dari Allah swt. Nilai ini juga mengandung nilai kemandirian, yaitu bekerja keras baik dalam kehidupan masyarakat maupun dalam kehidupan pembangunan daerah yang diridhai oleh Allah swt. Nilai religius yang yakin terhadap Tuhan terdapat dalam falsafah Tellui riala sappo: tanq- e ri dewata; siriq-e ri watakkaletaq; siriq-e ri padatta tau (artinya tiga hal yang dijadikan pagar/pelindung: Takut kepada tuhan (Allah swt); malu pada diri sendiri; malu pada sesama manusia. Dalam kehidupan di dunia ini, yang dijadikan sebagai penjaga bagi diri seorang yang utama adalah rasa takut atau malu kepada Allah Ta'ala, kemudian selanjutnya ditanamkan rasa malu terhadap diri sendiri dan malu kepada orang lain. Seorang yang memegang teguh ketiga prinsip tersebut, maka dirinya akan selamat dan terjaga dalam kehidupannya di dunia ini.

Tiga yang dijadikan pagar: rasa takut pada tuhan, rasa malu pada diri sendiri dan rasa malu kepada sesama manusia. Rasa malu kepada Tuhan membawa ketaqwaan dan memperkuat iman, rasa malu kepada diri sendiri akan menekan niat buruk dan memperhalus budi pekerti, dan rasa malu kepada sesama manusia akan membendung tingkah laku buruk dan meninggikan budi pekerti (A Moein MG., 1990)

Warisan leluhur orang Bugis yang terdapat dalam naskah lontaraq, jika dikaji secara mendalam dalam upaya memahami apa yang tersurat dan apa yang tersirat dalam naskah tersebut, maka akan ditemukan pertama-tama rasa kagum terhadap berbagai pandangan hidup yang merupakan falsafah leluhur orang Bugis pada masa lampau.

Berangkat dari kondisi yang dialami Kedatuan Luwu, maka dasar yang menjadi pegangan para cerdik pandai Kedatuan Luwu untuk merumuskan persyaratan bagi seseorang putra mahkota yang dapat mewarisi dan memegang kendali politik kedatuan, yaitu sebagai berikut: 1. Melempukpi (memelihara kejujuran) 2. Makekeda tongeppi (selalu berkata benar) 3. Maegettengpi (teguh pada pendirian yang benar) 4. Malelengpi (mawas diri) 5. Masempopi (bermurah hati) 6. Manyameng kininnawapi (memelihara sikap peramah) 7. Waranipi (memelihara keberanian) 8. Temmapasilaingeppi (tidak pilih kasih).

\section{Nilai-Nilai Periode Tomanurung}

Kondisi masyarakat dalam keadaan kacau dan bercerai berai. Karena itu, mereka mencari tokoh yang dapat mempersatukan masyarakat yang telah bercerai-berai dan dalam keadaan kacau (chaos). Melalui pencarian yang panjang, maka ditemukanlah orang yang mereka perlukan yaitu seorang Tomanurung (orang turun) dan mereka sepakat menjadikannya raja melalui suatu "perjanjian bersama" yaitu antara Tomanurung dengan wakil-wakil rakyat (Hadi Mulyono dan Abd Muthalib, 1979).

Masa Tomanurung pertama sampai datu Luwu ke-11 Datu Maningoe Ri Bajo (1551- 1581), badan pemerintahan Pakkatenni Ade' dan Ade'Asera tidak banyak berfungsi atau dengan kata lain pemerintahan yang dibangun di atas landasan demokrasi belum berjalan secara maksimal; dimana kebijakan pemerintah (raja) belum sepenuhnya memberi keberpihakan pada rakyat, pemerintah belum 
sepenuhnya memberikan perlindungan kepada rakyatnya, dan atau rakyat belum mendapat hak yang pantas dari raja, sampai datangnya periode Datu ke-12 yang bernama We Tenrirawe (1581-1611). Datu ke-12 ini dikenal menjalankan pemerintahannya dengan memberikan perhatian yang layak dan pantas buat rakyatnya; seperti yang digambarkan pada falsafah yang menjadi konstitusi pemerintahan Kedatuan Luwu. Pertama, "Puang temma bawang pawing ata tenri bawang pawang" (raja tidak boleh sewenang-wenang dan rakyat tidak boleh disewenang-wenangi). Maksud dasar hukum tersebut di atas, dititik beratkan pada sikap adil penguasa. Seorang pengusa tidak boleh bertindak sewenang-wenang terhadap rakyat, sebab kendatipun rakyat itu adalah ata (abdi), namun rakyat tetap berhak untuk diperlakukan secara adil (Sanusi Daeng Mattata, 1993).

Kedua, "Puang mappattutu ata ripattutu" (raja mendengar aspirasi rakyat dan rakyat harus menjelaskan aspirasinya). Konstitusi tersebut dimaksudkan agar seorang hakim yang bertugas memeriksa terdakwa, haruslah benar- benar menjalankan tugasnya sebagai hakim, yaitu sebelum menjatuhkan vonis, maka perkara tersebut, terlebih dahulu diteliti secara cermat. Seorang hakim berkewajiban memeriksa terlebih dahulu dalam rangka mencari kebenaran. Undang-undang di atas dijabarkan puladalam Lontara yang menyebutkan bahwa seorang hakim yang tidak menjalankan tugasnya secara profesional akan merusak negeri dan melemahkan kerajaan. Lebih lanjut Lontara menjelaskan, ada empat jenis hakim, tiga diantaranya dapat merusak negeri dan hanya satu yang memperbaiki negeri, yaitu, pertama, jika membuat keputusan atas dasar kebencian yakni melampiaskan kemarahan pribadinya, sehingga masalah yang ditanganinya merugikan pihak yang benar, kedua, hakim yang membuat keputusan dengan dasar kegembiraan, yaitu hakim yang menerima sogokan, ketiga, hakim yang membuat keputusan dengan dasar perasaan iba, yaitu hakim yang bermaksud melindungi dengan dasar keluarga, sehingga ia membenarkannya dan keempat, hakim yang mempertimbangkan kebenaran kedua belah pihak yang berperkara.

Ketiga, "Puang temmakketteni sulo ata tenriappaketenni sulo" (raja tidak memegang rakyat seperti obor, rakyat tidak dipegang seperti obor). Maksud dasar hukum tersebut, yakni penguasa harus mempunyai rasa tanggungjawab terhadap keadaan rakyatnya, sebab kemakmuran rakyat, berarti kemakmuran kerajaan. Sebaliknya, kesengsaraan rakyat berarti kesengsaraan kerajaan. Dengan demikian, antara penguasa dan rakyat tidak dapat dipisahkan. Penguasa berkuasa tetapi tetap mempunyai batas-batas kekuasaan. Demikian juga rakyat, mempunyai hak-hak yang harus dihormati oleh raja, sehingga penguasa harus mengetahui batas- batas kekuasaannya.

Berdasarkan konstitusi pemerintahan Kedatuan Luwu sebagaimana yang telah disebutkan di atas, maka penulis berkesimpulan, bahwa pada zaman pemerintahan Datu We Tenrirawe (1581- 1611), Kedatuan Luwu mengalami suatu revolusi. Datu We Tenrirawe sebagai seorang datu perempuan, berhasil melakukan revolusi membawa Kedatuan Luwu menjadi negara (state) yang sebelumnya bersifat monarki parlemen meningkat menjadi pemerintahan yang bersifat monarki konstitusional.

Datu perempuan ini sebagai sebuah revolusi, karena pemerintahan lahir dan dibangun dengan landasan demokrasi yang ditandai dengan adanya perjanjian kerja sama antara Tomanurung (Simpurusiang) dan wakil- wakil rakyat. Namun, merujuk kepada bunyi dasar-dasar hukum atau undang-undang pemerintahan tersebut di atas, maka jelaslah bahwa sebelum Datu Etenriawe (1581-1611), demokrasi belum berjalan sepenuhnya, atau dengan kata lain pemerintahan masih bercorak monarki parlementer, di mana masih melekat anggapan "raja tidak dapat berbuat salah," sehingga dengan image seperti itu, 
maka masih memberi peluang kepada pihak kerajaan untuk memperlakukan rakyat secara sewenangwenang dan tidak melibatkan rakyat dalam pemerintahan.

Kemungkinan besar, rakyat telah mengalami kejenuhan bahkan mungkin muncul gerakan-gerakan kecil dari rakyat. Memang penulis tidak menemukan referensi yang memberikan informasi mengenai gerakan- gerakan yang muncul dari masyarakat akibat mandeknya pemerintahan demokrasi yang diinginkan rakyat, tetapi kemungkinan untuk itu bisa saja terjadi sampai pada masa Datu Etenriawe (1581-1611), yang mau tidak mau, pihak kerajaan harus bekerja keras untuk melakukan suatu perubahan yang dapat dirasakan secara langsung olek rakyat. Penulis menduga, bahwa inilah yang melatar belakangi, lahirlahnya konstitusi baru Kedatuan Luwu, seperti yang disebutkan di atas. Pada masa Datu Etenriawe (1581-1611), dikenal seorang negarawan dan cendekiawan yang banyak memberikan perhatian terhadap kondisi kedatuan. Dia bernama Tociung. Tociung banyak memberikan ide-ide atau buah pikiran dan pesan-pesan kepada kedatuan/pemerintah yang bertujuan untuk memelihara kelangsungan kerajaan, sehingga kedatuan terhindar dari kehancuran (Sulesana Anwar Ibrahim, 2003).

Berdasarkan buah pikiran dan pesan- pesan dari Tociung, maka lahirlah hukum dasar pemerintahan Kedatuan Luwu yang berpihak kepada rakyat. Menurut Tociung, agar kerajaan dapat bertahan dan hidup terus, maka kedatuan harus pandai menyesuaikan diri dengan perubahan-perubahan yang telah menjadi kenyataan; kedatuan harus menyesuaikan diri dengan aspirasi rakyat, untuk itu, perlu diadakan perubahan-perubahan dalam kedatuan. Ide-ide dan pemikiran Tociung sangat membantu pemerintahan zaman Datu We Tenrirawe, karena itulah Tociung mendapat gelar "To Accana Luwu" (cendekiawan Luwu).

\section{Hasil Penelitian Dan Pembahasan}

Pangaderrang (adat istiadat) sebagai falsafah hidup orang Bugis, memiliki 4 (empat) asas sekaligus pilar yakni: (1) Asas mappasilasae, yakni memanifestasikan ade' bagi keserasian hidup dalam bersikap dan bertingkah laku memperlakukan diri dalam pangaderrang; (2) Mappasisaue, yakni diwujudkan sebagai manifestasi ade' (adat) untuk menimpahkan deraan pada setiap pelanggaran ade' (adat) yang dinyatakan dalam bicara. Azas ini menyatakan pedoman legalitas dan represi yang dijalankan dengan konsekuen; (3) Mappasenrupae, yakni mengamalkan ade' bagi kontinuitas pola-pola terdahulu yang dinyatakan dalam rapang; (4) Mappalaiseng, yakni manifestasi ade' dalam memilih dengan jelas batas hubungan antara manusia dengan institusi-institusi sosial, agar terhindar dari masalah (chaos) dan instabilitas lainnya. Hal ini dinyatakan dalam wari untuk setiap variasi perilakunya manusia Bugis. Masuk Islam di Tana Sulawesi Selatan, sangat mempengaruhi budaya Bugis. Dengan masuk Islam sehingga Falsafah Bugis yang dikenal 4 empat unsur (ade', bicara, rapang dan wari) kemudian ditambahkan dengan unsur sara' (Islam). Setelah Islam diterima sebagai agama resmi dan umum dalam masyarakat Bugis.

Falsafah yang mewarnai dan mendasari berbagai nilai perilaku manusia Bugis pada masa lampau. Beberapa kearifan Bugis dari berbagai sumber naskah lontaraq pappaseng yang mengandung nilai-nilai:

Nilai kejujuran 
Nilai-nilai kejujuran pada masyarakat Luwu sangat dijunjung tinggi sejak dahulu. Salah satu faktor yang sangat mendasari budaya orang Luwu (Bugis)dalam kehidupan sehari- hari adalah sifat kejujuran. Apabila kejujuran ini terabaikan maka akan menimbulkan keresahan, kegelisahan, dan penderitaan di kalangan masyarakat (Nuralam Saleh, 2006, Muhammad Sikki, dkk, 1991).

Berdasarkan kearifan yang terdapat dalam percakapan Penasihat raja Bone, Kajao Laliqdong dengan Arung Mpone tentang kejujuran. Anrê narekko taniya iko pasanreq-ki; Ajaq muala waramparang narekeko taniya waramparammu; Ajaq muala aju riwettawali narekko taniya ikompettai. (Jangan mengambil kayu yang disandarkan dan bukan engkau yang menyandarkan; Jangan mengambil barang-barang yang bukan milikmu; Jangan mengambil kayu yang ditetak ujung pangkalnya dan bukan kamu menetaknya (menebangnya).

Nilai tanggung jawab

Melaksanakan tugas dan kewajiban adalah perwujudan dari tanggung jawab yang harus dilakukan, baik pada dirinya sendiri, masyarakat, lingkungan (alam, sosial, budaya), negara dan Tuhan Yang Maha Esa. Pentingnya sikap tanggung jawab, telah ditekankan sejak dahulu. Hal ini terdapat dalam pappaseng: apa nakulle taue mabbaine narekko naulleni maggulilingini dapurêngnge wekkea pitu (Apabila seseorang pria ingin beristri, harus sanggup mengelilingi dapur tujuh kali. Seorang laki-laki yang telah dewasa, jika telah memiliki keinginan untuk berumah tangga, hendaknya mampu mengitari "dapur sebanyak tujuh kali".

Kata "dapur" di sini dijadikan suatu ibarat bahwa seorang yang ingin berumah tangga, berarti telah siap bertanggung jawab untuk memberikan nafkah kepada keluarganya. Adapun kata "tujuh" adalah hitungan hari dalam satu minggu terdapat tujuh hari. Jadi seorang laki-laki yang ingin berkeluarga, telah siap mencukupi kebutuhan seharihari dari orang yang kelak menjadi tanggungannya).

Nilai disiplin

Kedisiplinan adalah merupakan tindakan yang menunjukkan perilaku tertib dan patuh pada berbagai ketentuan dan peraturan. Sifat kepatuhan dan kesetiaan orang Bugis dalam berbagai aspek, seperti kepatuhan pada adat, dan kepatuhan kepada pemerintah. Hal ini terlihat pada pappaseng: Ajaq siyo mupinrai, murusaq-i, mubicarai Islam dan Kearifan Lokalmêng pura onroe, iyana ritu riasêng popo gamaru, makêrrêq. Natujui tikkaq wanuae, lelei saiye, makkamateng-matengngi tedongnge, oloq-koloe, têmmabbuai aju-kajung ri anrewe buwana, ri sappeyang pattapie, natuwoi sêrriq dapurêngngế; Iya natêppa kêrêkeênna nanre topi api adêq-e popo gamaru, rusaqe pura-onro, pura lalêng malêmpuq. narusaq deceng mallêbbang, napasalai tongêngnge napatujui salae; Naiya pura onroe, appunnanna tanae, appunnanna toi to maegae, appunnana toi arung-e. (Muhammad Sikki, dkk. 1998) Jangan sekali-kali engkau mengubah, merusak, dan membicarakan adat tetap karena itulah dinamakan popogamaru (makerre) pantangan besar dalam negeri. Jika hal itu dilakukan, negeri akan ditimpa kemarau panjang, penyakit mewabah, binatang ternak mati bergelimpangan, tak berbuah pepohonan yang dimakan buahnya, nyiru digantung, antan diselipkan, lesung ditelungkupkan, dapur ditumbuhi rumput.

Musibah itu tiba jika mengubah adat yang telah ada (membatalkan kesepakatan, mengubah tradisi), merusak nilai-nilai luhur yang dijunjung oleh masyarakat, menyalahkan yang benar, membenarkan yang salah. Adapun yang dimaksudkan tradisi ialah sesuatu yang milik bersama, milik orang banyak, dan milik raja). Maksudnya seseorang jangan sekali-kali membatalkan suatu kesepakatan, 
mengubah tradisi, merusak nilai-nilai luhur yang dijunjung oleh masyarakat, menyalahkan yang benar, membenarkan yang salah. Adapun yang dimaksudkan tradisi ialah sesuatu yang milik negeri, milik orang banyak, dan milik raja. Kalau hal tersebut dilanggar maka akan mendatangkan bencana dan musibah di negeri tersebut. Musibah yang dimaksud di sini adalah terjadi kekacauan di dalam negeri itu yang diakibatkan dari tidak dipatuhinya aturan- aturan yang ada.

Nilai kerja keras

Kerja keras adalah upaya sungguh- sungguh dalam mengatasi berbagai hambatan dan persoalan dalam kehidupan. Perilaku tersebut telah ditanamkan dalam budaya Bugis. Hal tersebut terlihat dalam pappaseng: Ajaq mumaeloq ribettang makekalêjjaq ricappaqna letengnge. (Muhammad Rapi Tang, 2004) Jangan mau didahului menginjakkan kaki di ujung titian dalam berusaha hendaknya bekerja dengan maksimal dan kepandaian untuk melihat peluang usaha. Hal ini menunjukkan bahwa dalam berusaha dibutuhkan perhatian dan kerja keras yang kompetitif).

Nilai Mandiri

Mandiri adalah sikap dan perilaku yang tidak mudah tergantung pada orang lain dalam menyelesaikan tugas. Sikap kemandirian ini sangat ditekankan dalam kearifan Bugis, seperti yang disebutkan dalam pappaseng ini: Mak.kedai pappasenna arung rioloe ri anana ri eppona ri siajinna rek.ko sappaqko dalleq koi mutajeng pammasena Allah ta'ala ri pammasena arung mangkanq-e. Enrengnge ri laonrumangnge. Kuwaeq leppang limammu. (Pananrangi, 1996). Berkata (pesan-pesan) raja terdahulu kepada anak cucunya, kepada kerabatnya. Kalau engkau mencari rezeki, nantikanlah rahmat Allah Ta'ala daripada belas kasih raja yang berkuasa, serta pada usaha bercocok tanam. Demikian pula dengan jerih payahmu sendiri).

Berusaha mandiri mencari rezeki dengan keringat sendiri, seperti menjadi seorang petani, sambal bercocok tanam senantiasa berdoa dan berharap rahmat dari Allah Ta'ala agar usaha yang dilakukan mendapatkan berkah dariNya. Bekerja sambil berdoa adalah lebih mulia daripada berharap belas kasihan dari orang lain.

Nilai peduli sosial

Peduli sosial adalah sikap dan perilaku yang mencerminkan kepedulian dan rasa cinta kepada orang lain (Pananrangi Hamid, 1996). Dalam menolong atau membantu orang lain hendaknya dengan hati yang ikhlas. Keikhlasan ini akan melahirkan suatu kepuasan dalam ikut meringankan beban orang lain, karena dilakukan tanpa pamrih dan berharap pujian dari manusia melainkan semata-mata mengharapkan pahala dan ridho dari Yang Maha Kuasa. seperti yang disebutkan dalam pappaseng ini: Galeccei alemu nampa mugalecce taune. Makna perkataan adalah cubit dulu dirimu, lalu kau cubit orang lain, jika sakit, maka sakit pula orang lain. Maknanya adalah sebelum menyakiti orang lain berpikir lebih dahulu.

Nilai peduli lingkungan

Kepedulian akan lingkungan alam dibuktikan dengan cara menggunakan alam sesuai dengan kebutuhan secara wajar dan seimbang (Paul Suparno, 2002). Berbagai pesan yang menggambarkan sikap dan tindakan yang selalu berupaya mencegah pada kerusakan lingkungan sekitar dan upaya untuk 
memperbaikinya, juga terdapat dalam pappaseng, Naiya rekko maelokeko mappalili madecenni maddepungeng $r i$ padangnge tasipakainge madeceng ribicaranna laonrumae ri billaqna bareq-e, timoq-e. Poncoqna bosie enrengnge lampeqna ri alemmana timoq-e, rimakerinna, nasabaq purana napalalo matowa pallaonrumae riaddapangi pole riadanna lontaraq-e enrengnge rapang lalonnae tau parekkengngengngi laonrrumae temmakekullei pasala. (Ambo Gani,1990) (Apabila engkau akan turun ke sawah, baiklah (engkau sekalian) berkumpul di padang kemudian saling memperingati (bermusyawarah), yang baik tentang musim kemarau, musim hujan, panjang dan lembutnya musim kemarau itu, keringnya udara, berdasarkan yang pernah dilaksanakan oleh Matowa (orang terdahulu yang paham) pertanian yang mengambil contoh seperti apa yang tertera dalam lontaraq, serta contoh yang pernah dilakukan oleh para ahli pertanian sebelumnya dan tak mengalami kesalahan).

Sipakatau, sipakalebbi, sipakaingge yaitu; semangat kebersamaan, sepenanggungan, seia- sekata dalam menjaga keharmonisan. Menurut Andi Mattingaragau (2019) untuk dapat mencapai ketentraman bersama, selalu dapat menjalin persahabatan kepada setiap orang dengan tanpa membedakan suku, agama, ras, dan golongan. Sedangkan padaidi, dilandasi dengan semangat kekeluargaan dan persaudaraan untuk selalu saling tolong menolong yang dapat ter-vitalisasi dan ter- implementasi secara lebih nyata dalam masyarakat, agarterjaga kerukunan, kebersamaan, keharmonisan, dan kenyamanan dalam menjalani kehidupan berbangsa dan bernegara.

Nilai merupakan nilai yang diartikan sebagai saling menghormati atau menghargai (sipakalebbi), saling menasehati (sipakainge), dan saling memuliakan (sipakatau), juga diartikan sebagai landasan seseorang atau kelompok dalam berperilaku kepada orang yang dituakan dan sesama teman maupun kepada yang lebih muda. Sipakalabbiri artinya saling menjaga kebersahajaan, menjaga keanggunan (perempuan), saling menjaga wibawa seseorang, atau bisa diartikan saling menghargai dan saling menghormati. Kalau ni pakalabbiri artinya diberi kedudukan yang terhormat. Masyarakat suku Bugis Makassar diharapkan sipakalabbiri, salah satu contohnya: seorang tamu wajib ni pakalabbiri, bagi siapa yang tidak dak mem pakalabbiri tamunya justru tuan rumahlah yang tidak labbiri (tidak terhormat) dimata masyarakat.

\section{Abbulo Sibatang}

Gotong royong, bekerjasama, bersatu/persatuan. Dalam keseharian kehidupan masyarakat suku Bugis, Makassar, Luwu dan Toraja yang ada di Kota Palopo selalu mengedepankan kegotong royongan, seperti memindahkan rumah panggung, menanam padi, memanen padi. Nilai abbulo sibatang ini juga yang mempererat hubungan silaturahim untuk selalu menjalin rasa kebersamaan dan persatuan antar saudara dan lain-lain.

Landasan hidup bersama dengan penuh cinta dan saling membantu serta mengingatkan terkandung dalam nilai mali siparappe, rebba sipatokkong, malilu sipakainge, khususnya saling membantu dalam kebaikan. Falsafah ini menitikberatkan pada rasa peduli yaitu sesama manusia, hendaknya saling membantu jika dalam kesulitan, saling menasehati dalam kebaikan, dan saling memotivasi jika dalam keadaan terpuruk, tidak semangat, bangkrut dan sebagainya. Nilai saling gotong royong ini telah dipraktikkan oleh masyarakat Bugis sejak dahulu. Hal ini dipraktikkan pada saat turun menanam padi di sawah, semua masyarakat dilibatkan dan mengambil andil ketika menanam padi. Selain menanam padi, gotong royong ditunjukkan ketika membangun rumah, memperbaiki jalan, membuat pengairan bagi sawah dan sebagainya. Karena hal itulah penulis merangkum dalam bagan ini. 


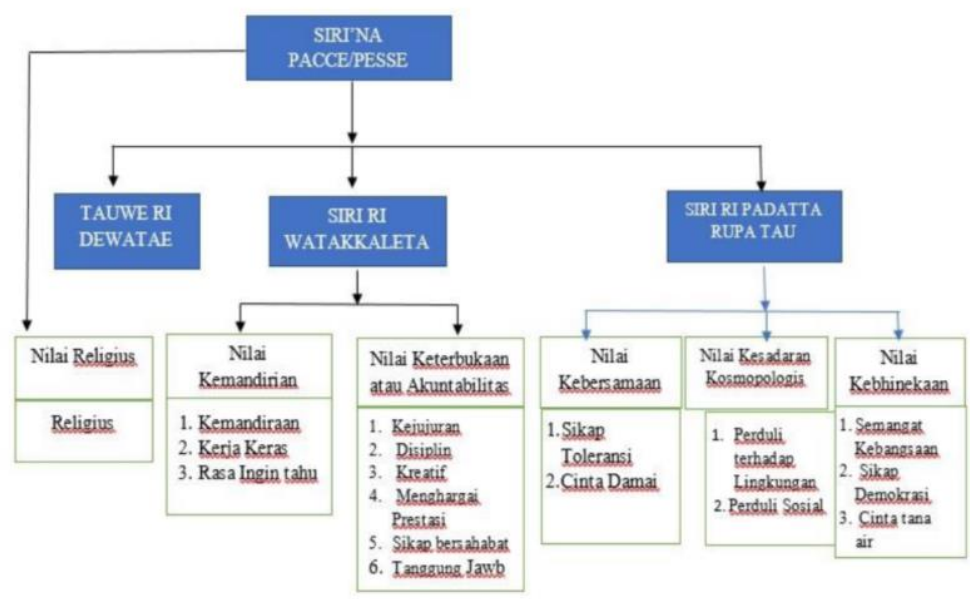

Nilai budaya lokal sebagai penjabaran konsep Siri na Pacce yang bisa menjadi acuan dalam berbagai aspek kehidupan: 1) Nilai kemandirian, yaitu bekerja keras baik dalam kehidupan masyarakat maupun dalam kehidupan pembangunan daerah yang diridhai oleh Allah swt. Dengan dasar nilai falsafah Resopa Temmangingngi Namalomo Naletei Pammase Dewata; 2) Nilai kebersamaan yang bertujuan untuk menjalin kerja sama saling menghargai sesama manusia yang berbasis pada falsafah Sipakatan Sipakalebbi, Sipakaingge; 3) Nilai keterbukaan atau akuntabilitas yaitu penegakan hukum secara tegas, jujur, adil dan transparan serta bertanggung jawab dalam kehidupan masyarakat dan pemerintah dengan dasar falsafah Lempu, Getteng, Ada Tongeng, Temmappasilaingeng, Nyameng Kininnawa. 4) Nilai kesadaran kosmopoligis yang berarti mempersatukan secara integral antara alam, manusia dengan sang Pencipta, saling melindungi, tolong menolong serta bertanggung jawab dalam melestarikan lingkungan alam maupun lingkungan sosial dengan dasar falsafah Rebba sipatokkong, Malilu sipakainge', Mali Siparappe' dan Abbulo Sibatang. 5) Nilai kebhinnekaan yang menghargai keragaman latar belakang suku dan budaya masyarakat, sebagai wujud dalam budaya bangsa yang sekaligus dapat dijadikan acuan dalam membangun dan membina rasa kebersamaan dan kesetiakawanan sosial dalam mendukung terciptanya kondisi harmonis dan dinamis bagi terselenggaranya pembangunan secara berkesinambungan dengan dasar falsafah Mallibu Tello, Mallibu Bulo, Mallibu Bare', Nenniya Siri' na Passe. (Berkeyakinan yang kuat, mengerjakan tanpa pamrih, walaupun sedikit yang mau melihat atau melirik, apa yang dilakukan dan apa pun resikonya harus di kerjakan) (Arhanuddin, Salim, ddk, 2018 Muhammad Ramli, 2008).

Dalam teori Talcott Parsons terkenal dengan empat imperatif fungsional bagi sistem tindakan yaitu skema AGIL. AGIL, fungsi adalah suatu gugusan aktivitas yang di arahkan untuk memenuhi satu atau beberapa kebutuhan sistem. Parsons menyakini bahwa perkembangan masyarakat berkaitan erat dengan perkembangan keempat unsur subsistem utama yaitu kultural (pendidikan), kehakiman (integrasi), pemerintahan (pencapaian tujuan) dan ekonomi (adaptasi) (J. Dwi Narwoko \& Bagong Suyanto, 2004).

Parsons percaya bahwa ada empat imperatif fungsional yang diperlukan atau menjadi ciri seluruh sistem adaptasi (A/adaptation), (Goal attainment/pencapaian tujuan), (Integrasi) dan (Latency) atau pemeliharaan pola Secara bersama-sama, keempat imperatif fungsional tersebut di sebut dengan skema AGIL. Agar bertahan hidup maka sistem harus menjalankan keempat fungsi tersebut. 
Pertama, Adaptasi, sistem harus mengatasi kebutuhan situasional yang datang dari luar. Masyarakat Bugis juga beradaptasi dengan lingkungan dan menyesuaikan lingkungan dengan kebutuhan-kebutuhannya.

Masyarakat pendatang Bugis jika dilihat dari segi kelompok masyarakat tergolong dalam kelompok outgroup yang harus menyesuaikan dirinya ke dalam kelompok in-group. Proses masyarakat pendatang Bugis dalam memenuhi kebutuhannya dari aspek sosial, di antaranya a) Interaksi yang terjadi antara masyarakat Bugis pendatang dengan masyarakat lokal; b) Proses mengatasi halangan-halangan dari lingkungan;

Pertama, dari aspek interaksi bahwa hal ini penting agar dapat diterima dalam lingkungan sosial. Kedua, dari aspek mengatasi halangan-halangan dari lingkungan yang dihadapi. Masyarakat suku Bugis memainkan peran agar dalam proses menghadapi halangan tersebut tidak berujung kepada kegagalan. Ketiga, dari aspek penyesuaian terhadap norma- norma dan budaya mesti pula dilakukan agar diterima dalam lingkungan sosial masyarakat lokal. Maksudnya pihak pendatang tersebut harus menerima dan menghormati budaya yang berlaku pada lingkungan sosial. keempat dari aspek memanfaatkan sumber daya, perlu diketahui dan dijadikan prinsip bagi masyarakat pendatang Bugis agar tetap eksis dalam menjalani kehidupannya. Selama keberadaan masyarakat pendatang Bugis di Tana Luwu. (Yunus, dan Fadli, H Subhan, 2020)

Dalam konteks sosial, sapaan dapat diartikan sebagai salah satu strategi berbahasa yang berfungsi untuk menguatkan hubungan sosial antar partisipan. Selain itu, penggunaan kata sapaan dapat berfungsi afektif, yaitu sebagai simbol penghormatan atau penghargaan penyapa kepada pesapa. Dalam penerapannya, penggunaan kata sapaan disesuaikan dengan status sosial yang melekat pada diri penyapa dan pesapa. Untuk itu, dalam konteks ini penggunaan sapaan akan dilihat berdasarkan (1) perbedaan status atau kedudukan sosial di antara kedua komunikan sebagai bentuk kekuasaan mereka. Kekuasaan (power $=K$ ) yang terkait dengan faktor sosial, yaitu usia, pendidikan, jabatan/pekerjaan, derajat keturunan atau status kebangsawanan yang bersangkutan, dan tingkat ekonomi; (2) jarak sosial atau hubungan keakraban antar keduanya (solidaritas $=$ S), dan (3) ada atau tidak ada orang yang mendengar dan ikut dalam perbincangan tersebut (publike =P) (Brown, 1987, Roger Brown dan Albert Gilman 1997).

Masyarakat pendatang Bugis telah lama menjalin hubungan sosial yang begitu kental dengan masyarakat Tana Luwu. Hal itu terbukti dalam bentuk kerjasama pada saat acara resepsi pernikahan masyarakat lokal, begitu pula sebaliknya. Selain itu, saat gotong royong yang dilaksanakan oleh masyarakat Luwu dan masyarakat Bugis juga ikut andil. Tentu saja, hal ini dapat menjadi modal sosial bagi masing- masing pihak agar ke depannya selalu berjalan berdampingan dalam menghadapi kendalakendala kehidupan. Kerjasama yang terbangun sesungguhnya dikarenakan oleh sikap saling menghargai dan menghormati antar suku bangsa sebagai identitas masyarakat bangsa Indonesia pada umumnya.

Gambaran dan pemahaman bahwa kearifan lokal sebenarnya bertujuan untuk menuntun mahasiswa agar mampu membangun tatanan kehidupan yang memposisikan manusia sebagai makhluk yang mulia yakni sipakatau. Demikian juga istilah sipakalebbi artinya saling memuliakan. Semua manusia merasa senang apabila dihormati dan dimuliakan oleh sesamanya, bahkan semua ajaran agama mengajarkan agar supaya saling menghormati dan saling memuliakan diantara sesama mahasiswa antara satu dengan yang lainnya. Perilaku saling menghormati dan mengahrgai telah dilakukan oleh masyarakat Bugis sejak dahulu, terutama yang dilakukan oleh orang yang yang lebih mudah ke yang lebih tua. 
Kedua, Pencapaian tujuan, sistem harus mendefinisikan dan mencapai tujuan-tujuan utamannya.

Sesama saudara hendaknya saling mengingatkan dalam kebaikan agar tidak terjerumus dalam perilaku yang tidak baik dan dapat merugikan siapa saja, baik merugikan diri sendiri maupun orang lain. Sehingga nilai-nilai sipakainge ini hendaknya selalu hadir dalam setiap kehidupan orang Luwu. Sipakalabbiri merupakan saling menghargai atau selalu ingin menghargai dan dihargai. Maka sifat Sipakalabbiri ini adalah wujud apresiasi. Sifat yang mampu melihat sisi baik dari orang lain dan memberikan ucapan bertutur kata yang baik atas prestasi yang telah diraihnya. Termasuk bertutur kata yang baik antara yang muda dan tua juga termasuk sipakalabbiri. Sipakatau merupakan sikap yang memanusiakan manusia seutuhnya dalam kondisi apapun. Sipakatau artinya saling memanusiakan. Dalam kehidupan sehari-hari, sangat diharapkan memperlakukan orang lain sebagaimana layaknya manusia, menjaga harkat dan martabat orang lain dan menjunjung tinggi hak azasi manusia. Nilai sipakatau ini yang mendorong keinginan saling tolong menolong antar sesama manusia. Sipakainge merupakan sifat saling mengingatkan untuk senantiasa melakukan kebaikan.

Ketiga, Integrasi, sistem harus mengatur hubungan bagian-bagian yang menjadi komponennya. Ia pun harus mengatur hubungan antar ketiga imperatif fungsional tersebut (A. G. L). Peduli dan suka membantu orang lain yang berada dalam posisi kesusahan adalah sikap terpuji yang senantiasa perlu dipupuk dan dipelihara. Anjuran peduli pada orang lain juga telah terekam dalam pappaseng: Limai passalêng namulolongêng decennge. Seuani, pakatunai alemu ri sitinajannae; maduanna, saroko mase ri sillalênnae; matelluna, makekareso patujue; maeppaqna, molae roppo-roppo narewêq; malimanna, molae laleng namatikeq. (Ada lima hal yang perlu diperhatikan jika ingin mendapatkan kebaikan. Pertama, rendahkanlah dirimu sewajarnya; kedua, bantulah orang lain pada tempatnya; ketiga, lakukanlah pekerjaan yang bermanfaat; keempat, hadapilah rintangan, kelima, ingatlah kembali kepada Tuhan; laluilah jalan dengan berhati-hati) (Zainuddin Hakim, 1992).

Keempat, Latency (pemeliharaan pola), sistem harus melengkapi, memelihara dan memperbaharui motivasi individu dan pola- pola budaya yang menciptakan dan mempertahankan motivasi tersebut (George Ritzer, 2004).

Budaya Bugis punya cinta dan kasih sayang terhadap sesama ditunjukkan dengan pepatah seperti mali siparappe, rebba sipatokkong, malilu sipakainge, Orang lain terhanyut, dibantu, orang lain terjatuh dibantu agar bangkit, orang lain keluar dari norma- norma diingatkan/diinsyafkan. Orang Bugis menghargai kedamaian, senang membantu sesama manusia, apalagi jika itu saudara sesama manusia.

Rasa hormat merupakan salah nilai kedamaian. Panggalik dalam kalimat dapat berupa saling menghormati (sipangngaliki) kepada sesama manusia. Hal ini dapat dilihat dari kalimat "Punna erokeko nipangngaliki, pangngaliki rong taua" artinya jika ingin dihormati, hormatilah orang terlebih dahulu. Panggalik juga dapat diartikan rasa malu, kepemilikan pangngalik bagi suku makassar sangat penting, karena dengan adanya pangngalik bagi diri seseorang, mencegah seseorang bertindak tidak sesuai dengan nilai- nilai moral. Kalau ada seseorang dalam masyarakat suku Bugis yang disebut tau tena pangngalikna (orang yang tidak memiliki rasa malu) itu berarti orang tersebut sudah tidak punya harga diri dan dianggap seperti layaknya binatang. Begitu pula sebaliknya, kalau ada seseorang yang disebut tau tinggi pangngalikna, berarti orang tersebut sangat menjaga perbuatannya dari pelanggaran moral. Orang tersebut dihargai dalam masyarakat dan menjadi teladan dalam perilaku kesehariannya. "Abbulo sibatang 
paki antu, mareso tamattappu nanampa nia sannang ni pusakai (bambu sebatang semua kita, bekerja tak putus-putus, dan kemudian senang dimiliki). Maksudnya adalah seperti satu batang bambu kita bekerja terus sama-sama akan kita dapati kesenangan. Nilai ini merupakan semangat bergotong royong dalam mengerjakan sesuatu sehingga mudah untuk dilakukan dan mempererat kebersamaan.

Interaksi sosial di masyarakat, mereka biasanya mengedepankan akhlak atau etika yang terimplementasi pada filosofi pada idi (kita semua bersaudara). Menurut Hadrawi, filosofi ini sebenarnya terambil dari dua prinsip dasar agama Islam, yaitu takwa dan tauhid. Menurutnya, takwa dan tauhid merupakan salah satu terma religiositas utama yang bisa mengukur tingkat moralitas atau etika dan konsistensi keimanan seorang muslim terhadap ajarannya (Hadrawi, 2019). Menurut Farid Esack, sebagaimana dikutip oleh Ahmala Arifin, secara hermeneutik, signifikansi dari konsep takwa di sini adalah bagaimana cara al-Qur'an mengaitkan takwa dengan interaksi sosial dan solidaritas pada sesama. Dalam al-Qur'an dijelaskan, bahwa komitmen pada makhluk Tuhan (ciptaan Tuhan), adalah bagian yang tak terpisahkan dengan dari komitmen kepada Tuhan (Ahmala Arifin, 2015). Karena selain berpengaruh bagi diri seseorang, takwa juga terkait dengan praktik sosial. Seseorang yang teguh dengan komitmen ketakwaannya, maka ia akan memiliki sense of belonging terhadap sesama dan juga terhadap realitas yang tidak adil.

Sementara tauhid merupakan basis ontologis bagi pandangan dunia al-Qur'an yang berpengaruh terhadap struktur pengetahuan dan tindakan praksis lainnya yang berimplikasi pada aktivitas sosial sejak permulaan misi profetik-nya. Dari semula, ajaran tauhid selalu diliputi oleh dua dimensi, yaitu dimensi normativitas akidah dan dimensi praksis sosial. Ungkapan al-Qur'an bahwa "iman" harus selalu disertai dengan "amal saleh" merupakan autentisitas ajaran al-Qur'an. Jangankan ajaran tauhid yang biasanya masuk dalam wilayah arka $>n$ al-Ima $>n$ yang bersifat abstrak, dalam wilayah arka $>n$ al-Isla $>m$ pun, ibadah mahdha $>b$ seperti salat juga selalu dikaitkan dengan dimensi sosial. Ditegakkannya salat juga untuk menjaga diri seseorang dari perbuatan yang keji (fakbsya $>$ ') dan buruk (munka $>r$ ). (M. Amin Abdullah, 2000). Begitu juga dengan ibadah haji, zakat, infak, sedekah, dan sebagainya. Sehingga ajaran tauhid menurut al- Qur'an sangat terkait dengan persoalan- persoalan sosial, yaitu mengidealkan suatu tatanan masyarakat yang damai atas dasar kemanusiaan dengan tidak mengeksploitasi perbedaanperbedaan (Farid Esack, 1977). Jika takwa dan tauhid diimplementasikan dengan benar, maka agama Islam sebagaimana dikatakan oleh Azyumardi Azra, dapat memainkan peran penting untuk menciptakan perdamaian dunia (Azyumardi Azra, 2014).

Filosofi patedunggi, oleh masyarakat Kota Palopo dijadikan sebagai landasan awal dalam berinteraksi dengan masyarakat yang beranekaragam agama, suku, dan budaya. Lebih jauh, hal ini didasarkan adagium berbentuk syair Arab yang berbunyi "Sesungguhnya bangsa-bangsa itu akan tegak selama akhlaknya pun tegak dan jika akhlaknya runtuh, maka runtuh pulalah bangsa itu." Ini berarti, bahwa kejayaan suatu bangsa tergantung kepada keteguhan akhlak, budi pekerti atau moral dari bangsa itu sendiri, sebab inti ketakwaan dari pengamalan agama adalah berbudi luhur.

Masing-masing daerah memiliki adat- istiadat berbeda satu dengan yang lainnya. Ketika adat itu diterima dan dianggap baik, maka adat tersebut melekat dan membentuk karakter pada setiap individu di daerah tersebut. Dalam bahasa al-Qur'an, kebiasaan baik dinamai ma'ru>f, yakni dikenal atau disetujui, sedangkan kalau buruk dinamai mungka $>r$, yakni diingkari dan ditolak oleh suatu masyarakat. Dengan demikian, akhlak atau etika adalah sekumpulan nilai yang harus diindahkan manusia dalam 
menjalani aktivitasnya demi terciptanya hubungan yang harmonis, demi meraih kebahagiaan pribadi dan masyarakat. Seperti gambar dibawah ini menunjukkan aktivitas keagamaan yang terbuka terhadap perbedaan.

Manusia yang berakhlak mulia adalah manusia yang beragama, taat pada perintah- perintah Tuhan, serta senantiasa menghargai martabat sesamanya. Analogi yang sama oleh dikatakan Deschovski, sebagaimana dikutip oleh Ayatullah Murtadha Muthahhari (2011) berkata bahwa "seandainya Tuhan tidak ada, maka segala sesuatu diperbolehkan". Maksudnya adalah bahwa jika tanpa agama, maka niscaya tidak akan ada nilai-nilai yang melarang manusia dari perbuatan-perbuatan immoralnya. Agama adalah satu-satunya jaminan bagi penerapan etika atau akbla $>k$ al- Kari $>$ mah. Apalagi pengalaman telah membuktikan, bahwa nilai-nilai agama mendahului nilai-nilai etika. Karena itu aliran- aliran etika ateis tidak pernah berhasil dalam penerapan nilai-nilai etika. Bagaimanapun juga, agama sangat penting sebagai fondasi etika, karena itu setinggi apapun kemajuan manusia di bidang teknologi dan peradaban.

Gambaran kehidupan keagamaan di atas, terlihat jelas bagaimana kita menempatkan akhlak sebagai fondasi dasar dalam berinteraksi atau hidup di tengah kondisi masyarakat yang majemuk. Pengalaman telah membuktikan, bahwa dengan menggunakan pendekatan akhlak atau etika, sesuatu yang tadinya keras, kencang, akan menjadi lembut, halus, dan mencair. Apalagi jika pengejawantahan akhlak tersebut dirasa rasional atau dapat dicerna oleh akal, sehingga akan mengarahkan kepada rasa simpati dan empati manusia, yang menggerakkan emosional dengan bingkisan spiritual, sehingga semua aktivitas yang dilakukan diridhai Allah swt.

Kemudian persatuan bagaikan bulat beras, dimaknai sebagai suatu persatuan yang bersifat vertikal adalah persatuan antara raja atau pemimpin dengan rakyatnya, sehingga apa yang menjadi kebesaran dari sang raja, akan menjadi kekuatan bagi sang hamba. Tidak ada saling mencurigai antara raja dengan rakyatnya, rakyat tidak menginginkan kedudukan raja, demikian juga sang raja tidak ingin diperhambakan oleh rakyatnya. Tidak ada saling memarahi dan saling dendam. Hubungan baik antara raja atau pemimpin dengan rakyat berjalan sampai pada anak cucu. Kemudian persatuan bulat bagaikan buluh bambu, yakni antara raja atau pemimpin dengan rakyatnya bersatu dalam suka maupun duka. Sehingga apabila salah satunya khilaf maka saling mengingatkan, apabila jatuh, maka saling membangkitkan. Persatuan ini merupakan persatuan buluh bambu antara bulat di luar dengan di dalam sama, sehingga apabila rusak di luar, maka rusak pulalah di dalam.

\section{Penutup}

Bagi Masyarakat Luwu (Bugis) nilai-nilai terdapat dalam periode lontarak/tomanurung, sesuati nilai berkaitan kehidupan sosial. Mengimpmentasikan nilai-nilai tomanurung adalah suatu sikap yang bertujuan untuk membuat orang lain suka atau merasa nyaman dan aman. Beberapa sikap yang biasa diimplementasikan oleh masyarakat Luwu yang bersumber dari lontarak antara lain; ramah kepada siapapun, suka menolong, bersikap sesuai dengan norma dan tata kerama yang telah ditentukandidasarkan pada pedoman dalam etika kehidupan sehari-hari yang disusun sangat pendek namun memiliki makna yang sangat bermanfaat, yaitu; tidak sombong dengan sifat maegettengpi serta selalu berusaha untuk mengoreksi diri sendiri. Karena kedamaian merupakan landasan dan pedoman yang 
dianut dalam berperilaku bagi masyarakat Luwu. Ada berbagai sumber yang mengandung nilai-nilai kedamaian seperti Abbulo Sibatang.

\section{Daftar Pustaka}

A. Fishman (ed). (1997). Readings in Sociologi of Languange (Paris: The Hangue Mouton.

Abdullah, M. Amin. (2000). Dinamika Islam Kultural: Pemetaan atas Wacana Keislaman Kontemporer. Bandung: Mizan. Anton, Andi. (1993). Pangeran, “Upacara 'Ripasekko Pajung Pulaweng” (Penobatan Pajung Pulaweng).” Ujungpandang: Panitia Pelaksana Pagelaran Budaya Luwu.

Arifin, Ahmala. (2015). Tafsir Pembebasan: Metode Interpretasi Profresif ala Farid Esack. Yogyakarta: Aura Pustaka.

Azra, Azyumardi. (2014). “Agama untuk Perdamaian Dunia”, Republika, Kamis 14 August.

Brown, Penelope and Stephen C Levinson. Politeness. (1987). Some Unoversals in Languange Usage. Studies in Interaction Sociolinguistics. New York: Cambridge University Press.

Esack, Farid. (1977). Qur'an, Liberation, Pluralism: An Islamic Perspective of Interreligious Solidarity against Oppression. Oxford: One world.

Gani, Ambo dkk. (1990). Wasiat-Wasiat dalam Lontarak Bugis (Jakarta: Departemen Pendidikan dan Kebudayaan.

Hadrawi. (2019). Salah Satu Penulis Prospek Pesantren Tana Luwu, Wawancara, 16 Februari di Malangke Desa Cenning.

Hakim. Zainuddin. (1992) Pangngajak Tomatoa. Jakarta: Pusat Pembinaan dan Pengembangan Bahasa Depdikbud.

Mattingaragau, Andi. 2019.Wakil Rektor 1 UNANDA, Wawancara, 14 Februari

MG., A Moein. (1990). Menggali Nilai-Nilai Budaya Bugis Makassar dan Siri' Na Pacce, Ujung Pandang: Yayasan Mapress.

Mulyono, Hadi dan Abd Muthalib. (1979). Sejarah Kuno Sulawesi-selatan, Ujungpandang: Suaka Peninggalan sjarah dan Purbakala Sulawesi-selatan

Murtadha Muthahhari, Ayatullah. (2011). Dasar-Dasar Epistemologi Pendidikan Islam. Jakarta: Sadra Press.

Narwoko J. Dwi \& Bagong Suyanto (2004). Sosiologi Teks Pengantar dan Terapan, Jakarta: Prenada Media.

Pananrangi, Hamid. (1996) "Pemahaman Budaya Sulawesi Selatan tentang Nilai Pendidikan, Karya, dan Kepemimpinan Menurut Lontarak", dalam Bosara Media Informasi Sejarah dan Budaya SulSel No. 4 Th. III, (Ujung Pandang: Depdikbud Dirjen Kebudayaan BKSNT. 
Paul Suparno. (2002). Pendidikan Budi Pekerti di Sekolah Suatu Tinjauan Umum. Yogyakarta: Kanisius.

Ramli, Muhammad. (2008) "Sinergitas Kearifan Lokal Masyarakat Bugis dalam Impelementasi Kebijakan Publik di Kabupaten Sidenreng Rappang”, Disertasi, Makassar: Program Pascasarjana Universitas Hasanuddin Makassar.

Rapi Tang, Muhammad, (2004) "Reso sebagai Roh Kehidupan Manusia Bugis: Budaya dari Sisi Mental dan Fisik", dalam makalah Seminar dan Diskusi Peningkatan Apresiasi Masyarakat tentang Budaya Disiplin, Makassar: Kemenbudpar BKSNT bekerjasama dengan Fakultas Sastra Unhas.

Ritzer, George. (2004). Edisi terbaru Teori Sosiologi. Yogyakarta: Kreasi Wacana.

Salim. Arhanuddin Yunus Salik, and Ismail Suwardi Wekke. (2018)"Pendidikan Karakter dalam Masyarakat Bugis." Ijtimaiyya: Jurnal Pengembangan Masyarakat Islam 11, no. 1: 41-62.

Saleh, Nuralam. (2016). "Pappasang Turiolo (Revitalisasi Nilai-Nilai Budaya dalam Kehidupan Orang Makassar", dalam Walasuji Vol I, (1), Januari-April.

Sikki, Muhammad, dkk. (1998) Nilai dan Manfaat Pappaseng dalam Sastra Bugis. Jakarta: Pusat Pembinaan dan Pengembangan Bahasa Depdikbud.

Sulesana Anwar Ibrahim. (2003) Kumpulan Esai tentang Demokrasi dan Kearifan Lokal. Makassar: Lembaga Penerbitan Universitas Hasanuddin.

Yunus, Subhan Fadli Pluralisme dalam Bingkai Budaya, Yogjakarta: Bintang Pustaka, 2020.

Zuriah, Nurul. (2007) Pendidikan Moral \& Budi Pekerti dalam Perspektif Perubahan: Menggagas Platform Pendidikan Budi Pekerti Secara Kontekstual dan Futuristik. Jakarta: Bumi Aksara. 